九州大学学術情報リポジトリ

Kyushu University Institutional Repository

\title{
Healing Environments of Major Tree Species in Kyushu University Forests : A Case Study
}

\section{Kim, Geonwoo}

Department of Environment and Foret Resources, College of Agriculture \& Life Sciences, Chungnam National University

Park, Bum-Jin

Department of Environment and Foret Resources, College of Agriculture \& Life Sciences, Chungnam National University

\section{Joung, Dawou}

Department of Environment and Foret Resources, College of Agriculture \& Life Sciences, Chungnam National University

Yeom, Dong-Geol

Department of Environment and Foret Resources, College of Agriculture \& Life Sciences, Chungnam National University

他

https://doi.org/10.5109/1543412

出版情報: 九州大学大学院農学研究院紀要. 60 (2)，pp.477-483，2015-09-18. Faculty of Agriculture, Kyushu University

バージョン：

権利関係 : 


\title{
Healing Environments of Major Tree Species in Kyushu University Forests: A Case Study
}

\author{
Geonwoo KIM ${ }^{1}$, Bum-Jin PARK ${ }^{1 *}$, Dawou JOUNG ${ }^{1}$, \\ Dong-Geol YEOM ${ }^{1}$ and Shinya KOGA
}

\author{
Laboratory of Forest Resources Management, Division of Forest Environmental Sciences, \\ Department of Agro-environmental Sciences, Faculty of Agriculture, \\ Kyushu University, Sasaguri, Fukuoka 811-2415, Japan \\ (Received May 15, 2015 and accepted May 19, 2015)
}

\begin{abstract}
The present study was performed to compare healing environments among five tree species in the Kasuya Research Forest of Kyushu University. Measurements of forest stand-specific natural volatile organic compound (NVOC) concentrations and predicted mean vote (PMV) and predicted percentage of dissatisfied (PPD) indexes were performed simultaneously in the same region. Samplings were performed using Tenax TA-filled tubes and mini pumps to collect NVOCs in the forest air. The collected NVOCs were analyzed using gas chromatography-mass spectrometry. In addition, measurements of physical features of the forest environment (including temperature, humidity, wind velocity, and illumination intensity) were performed at a time interval of $1 \mathrm{~min}$. Eucalyptus gomphocephala emitted the highest concentration of NVOCs $\left(3.13 \mathrm{ng} / \mathrm{m}^{3}\right)$. Thermal comfort was the highest in E. saligna community (PMV: -0.1 ; PPD: 6.9\%), which revealed that Eucalyptus species has an excellent healing environment. The data obtained from this study may be used as beneficial information for citizens, who in turn will view the value of forest in a new perspective.
\end{abstract}

Key words: $N V O C$, Terpene, PMV, PPD, University Forest

\section{INTRODUCTION}

Forests have closely been related to human life even till today. They serve multipurpose functions for the people, such as production of forest products, including wood, national land preservation through air purification and water source protection, and providing habitats for wild animals. In recent years, there has been a great emphasis on the simultaneous pursuit of health and happiness, which is making forest protection and non-wood production to be replaced with forest recreation and healing as a priority of forest use. This requires modifying the existing forests to be more sustainable through effective management.

University forests play an important role in the experimental and research studies related to the use of forest resources. When forest protection and wood production were active in the past, the revitalization of regional economy was accomplished through the forests (Kim et al., 2003), but recent changes in forest functions have necessitated research and education as well as recreational role of forests for local residents.

The Kasuya Research Forest of Kyushu University in Japan has been subjected to sufficient and concrete surveys, but its vegetation features have not sufficiently been studied with the object of healing environments, although there are various healing environment elements in forests. This study evaluated the concentrations of natural volatile organic compounds (NVOCs) and the predicted

\footnotetext{
1 Department of Environment and Forest Resources, College of Agriculture \& Life Sciences, Chungnam National University, 99 Daehak-ro, Yuseong-gu, Daejeon 305-764, Republic of Korea

* Corresponding author (E-mail: bjpark@cnu.ac.kr)
}

mean vote (PMV) and predicted percentage of dissatisfied (PPD) indexes, which can be calculated in detail. The NVOCs released from the forests are widely known by the name phytoncide. The thus far discovered phytoncides include volatile or liquid substances and also solids; those that directly come in contact with the body while walking in a forest are volatile phytoncides released into the air by plants (Ohira and Matsui, 2012). Phytoncides are known to have different characteristics depending on their constituent elements, which include insect-proof, antibacterial, anticancer, antioxidant, antistress, and immunity-boosting properties (Dayawansa et al., 2003; Akutsu et al., 2006; Li et al., 2006). Other healing environment elements such as PMV and PPD were reported to make persons feel cooler and more comfortable in waking activities in forest than in cities (Takayama et al., 2005; Honjo, 2009). When enjoying a forest landscape, subjects showed significantly low values of LF/LF + HF of systolic blood pressure and chronotropy, as compared to when enjoying a city scenery (Park et al., 2010). Similarly, an increase in physiological parameters was observed in a study on healing with forest resources. The interest in forests is also on the increase, as shown by the increasing number of people visiting the forests with the purpose of improving their health.

Therefore, this study aimed to offer scientific data from the viewpoint of health by conducting on-site analyses of NVOC components and evaluating thermal comfort indexes of PMV and PPD of major tree species in the Kasuya Research Forest of Kyushu University, which plays important roles in citizens' recreation and students' learning, in the same region and time zone. 


\section{MATERIALS AND METHODS}

\section{Study site}

The study site is the Kasuya Research Forest of Kyushu University, an urban forest that is located in $33^{\circ}$ $38^{\prime} 15.2^{\prime \prime} \mathrm{N} 130^{\circ} 30^{\prime} 51.1^{\prime \prime} \mathrm{E}$, easy for citizens to visit, well preserved, and excellent in landscape. The forest with an area of about 500 ha consists of tree species dominated by Japanese cedar and cypress and is a target area for active studies on forest hydraulics and medicinal plants. This study focused on the measurements of Chamaecyparis obtusa, Cryptomeria japonica, Lithocarpus edulis, Eucalyptus saligna, and E. gomphocephala.

\section{Measurement factors NVOCs}

Volatile organic compounds (VOCs) are either liquid or gaseous organic compounds that have boiling points below $100^{\circ} \mathrm{C}$ and are easily evaporated into the atmosphere. This study concentrated on the methods of analyzing NVOCs. The majority of NVOCs emitted in the forests are generated by trees. Terpene compounds, which are a kind of NVOCs emitted by trees, are produced from multiple base units of isoprene, which contains five carbon and eight hydrogen atoms. Terpenoids, a common and large NVOC group, consist of hemiterpenes, monoterpenes, and sesquiterpenes. Emission inventories show isoprene and monoterpenes as the most prominent compounds. Usually, these compounds are strong smelling, hardly water soluble, and found in plants as well as in animals and microorganisms (Kesselmeier and Staudt, 1999). In the present study, 20 species of isoprenes and monoterpenes (99\%, Sigma-Aldrich, USA), including isoprene, $\alpha$-pinene, $\beta$-pinene, and camphene, were selected for analysis (Table 1 ).

\section{Selection of measurement materials}

As part of an effort of the Forest Science \& Technology projects, the Korea Forest Service recently performed a material contents survey pertaining to the health effects of NVOCs, by selecting 20 species elements emitted from various coniferous species. According to the Model of Emissions of Gases and Aerosols from Nature 2.1 released by the National Center for Atmospheric Research in 2012, more than 25,000 types of VOCs and 147 chemical species of NVOCs are estimated to be emitted into the atmosphere by plants, more than half of which are terpenes that comprise 53 species of materials out of the total 147. There are several research studies that have analyzed the effects of NVOCs and how to cope up with the diseases they cause (Kim et al., 2008; Kordali et al., 2008; Bräred-Christensson et al., 2012; Wang et al., 2012, Osman et al., 2011). Therefore, unlike previous efforts to analyze NVOCs, we surveyed the existing literature to determine how materials have been observed to affect the body thus far. The primary keywords for the literature search were BRM (biological response modifier), phytochemicals, nutraceuticals (nutrition and pharmaceuticals), aromas, and essential oils. Accordingly, keywords resulting in high frequency outputs from previous studies were used in this study to guide the selection of materials to represent VOC types present in the atmosphere.

\section{Predicted mean vote and predicted percentage of dis- satisfied}

Thermal balance is obtained when the internal heat production in the body equals the loss of heat to the environment. In a moderate environment, the human thermoregulatory system will automatically attempt to modify the skin temperature and sweat secretion to maintain heat balance. The PMV is an index that predicts the mean value of the thermal votes of a large group of people exposed to the same environment on a 7-point thermal sensation scale, based on the heat balance of the human body. But individual votes are scattered around this mean value and it is useful to be able to predict the number of people likely to feel uncomfortably warm or cool. The PPD is an index that establishes a quantitative prediction of the percentage of thermally dissatisfied people who feel too cool or too warm. For the purpose of this international standard, thermally dissatisfied people are considered as those who will vote hot, warm, cool or cold on the 7-point thermal sensation scale (ISO 7730, 2005).

\section{Measurement methods} NVOCS

The adsorption tube method was used in this study to collect samples. The tube (Makers, USA) filled with Tenax TA and Carbotrap 2B was used for adsorption. The sample capture device was a mini pump (MP- $-230 \mathrm{KN}$, SIBATA, Japan), and the calibration was proceeded by calculation of adsorption error prior to the use of a flow meter. A total volume of $9 \mathrm{~L}$ of NVOCs was collected at a flow rate of $100 \mathrm{~mL} / \mathrm{min}$. The sampling equipment was installed in accordance with the horizontal height of the tripod, $1.5 \mathrm{~m}$ from the ground, and the average value was calculated through duplicate sampling at every location. Disposable polyethylene gloves and antibacterial masks

Table 1. List of measurement materials

\begin{tabular}{lccc}
\hline isoprene & $(+)-\alpha$-pinene & camphene & $(-)-\beta$-pinene \\
myrcene & $\alpha$-phellandrene & $(1 \mathrm{~s})$ - $(+)$-3-carene & $\alpha$-terpinene \\
p-cymene & $(\mathrm{r})-(+)$-limonene & eucalyptol (cineole) & $\gamma$-terpinene \\
linalool & terpinolene & $( \pm)$-camphor & terpineol \\
bornyl acetate & $(-)$-trans-caryophyllene & $\alpha$-humulene & $(+)$-cedrol \\
\hline
\end{tabular}


were used to prevent artificial error when in contact with the tube during installation. After sampling, the sample tubes were maintained at temperatures below $4^{\circ} \mathrm{C}$ and analyzed within $48 \mathrm{~h}$. The samples were subjected to qualitative and quantitative analyses using a gas chromatography (GC)/mass spectrometer (7890N-5975, Agilent, USA) with thermal desorption system (GC/MSD, Gerstel TDS, Gerstel, Germany). The substances adsorbed by the adsorption tube were concentrated in a low-temperature cryofocusing device, which inhales high-purity helium gas at a velocity of $1 \mathrm{~mL} / \mathrm{min}$ from a thermal desorption device, thermodesorbes the gas for $3 \mathrm{~min}$ at $210^{\circ} \mathrm{C}$, and keeps its temperature at $-30^{\circ} \mathrm{C}$. The substances were then subjected to thermal desorption for 3 min at $220^{\circ} \mathrm{C}$, infused into a GC spectrometer, and detected with an MSD.

\section{Calibration curve}

There are few tests to confirm the results of both the analysis device and the procedures. First, this study used 20 species of standard materials, such as $\alpha$-pinene and $\beta$-pinene, to obtain the calibration curve. Using the calibration curve to calculate each element's mass number and the square of its rate of diluting standard materials, it was deduced that a majority of the materials has a linearity greater than $0.997, e . g ., \alpha$-pinene $\left(R^{2}=0.997\right)$, $\beta$-pinene $\left(R^{2}=0.998\right)$, and D-limonene $\left(R^{2}=0.999\right)$ (Fig. 1). The experiments using these materials also have a high reproducibility with respect to the coefficient of determination, which is suitable for analysis.

\section{Vegetation survey}

A quadrant of $20 \mathrm{~m} \times 20 \mathrm{~m}$ was established in a NVOC measurement site, and plant species were divided into tree layer, subtree layer, shrub layer, and herb layer for conducting a plant sociological survey. A record of the average tree height and crown projection chart of the tree layer was prepared. A log-wood survey of tree species measuring $\geq 2 \mathrm{~cm}$ in diameter at breast height (DBH) in the study site was performed. The direction and the slope of the site were measured in terms of the locational environment. A setup was made to ensure that a portable multifunction meter (Poly MI 6401, METREL, Slovenia) maintains the physical features of the site environment (temperature, humidity, wind velocity, dew point, globe temperature, air current, and wet-bulb globe temperature) at intervals of $1 \mathrm{~min}$. The meter was installed at a height of $1.5 \mathrm{~m}$ in equilibrium using a tripod around $1 \mathrm{~m}$ from a mini pump, and digitalized measurement results were saved and then converted for analysis. The results were analyzed using the Sensor Link PRO program (METREL, Slovenia). The data saved 5 min before and after measurement were excluded from the analysis to minimize measurement error.

\section{RESULTS}

\section{Variation of NVOCs}

A total of 17 materials were detected from the analysis of 20 NVOCs, including $\alpha$-pinene (Fig. 2). Isoprene turned out to be of the highest concentration among the materials. Most of them were similar in the distribution of concentration characteristics. They were high in concentration in the order of $\alpha$-pinene $>$ camphor $>$ camphene. C. japonica, E. saligna, and E. gomphocephala emitted higher concentrations of $\alpha$-pinene $(0.578 \mathrm{ng} /$ $\left.\mathrm{m}^{3}\right)$ and camphene $\left(0.179 \mathrm{ng} / \mathrm{m}^{3}\right)$, cineole $\left(0.222 \mathrm{ng} / \mathrm{m}^{3}\right)$, and $\beta$-pinene $\left(0.120 \mathrm{ng} / \mathrm{m}^{3}\right)$ and cymene $\left(0.279 \mathrm{ng} / \mathrm{m}^{3}\right)$, respectively, than other tree species (Fig. 2).

The TNVOCs revised by flow rates in C. obtusa, $C$. japonica, L. edulis, E. saligna, and E. gomphocephala were $1.31 \mathrm{ng} / \mathrm{m}^{3}, 1.59 \mathrm{ng} / \mathrm{m}^{3}, 1.15 \mathrm{ng} / \mathrm{m}^{3}, 1.35 \mathrm{ng} / \mathrm{m}^{3}$, and $1.63 \mathrm{ng} / \mathrm{m}^{3}$, respectively (Fig. 3). E. gomphocephala emitted the highest concentration of NVOCs.

\section{Results of Vegetation survey}

\section{C. obtusa community}

The C. obtusa community had a DBH of $\geq 30 \mathrm{~cm}$ and a relatively steep slope of $32^{\circ}$. The tree layer had an average tree height of $18 \mathrm{~m}$ and two tree species (Fig. 4). The average temperature, humidity, wind velocity, and black globe temperature of the site were $17.7^{\circ} \mathrm{C}, 94.8 \%$, $0.5 \mathrm{~m} / \mathrm{s}$, and $18.4^{\circ} \mathrm{C}$, respectively, and the PMV and PPD were -1.2 and $39.6 \%$, respectively.

\section{C. japonica community}

The $C$. japonica community had a DBH of $\geq 38 \mathrm{~cm}$ and a relatively steep slope of $21^{\circ}$ (Fig. 5). The tree layer had an average tree height of $15 \mathrm{~m}$. The average temperature, humidity, wind velocity, and black globe tempera-

Table 2. GC/MS operating parameters for NVOCs

\begin{tabular}{|c|c|c|c|c|c|}
\hline Parameter & \multicolumn{5}{|c|}{ Condition } \\
\hline Column & \multicolumn{5}{|c|}{ HP-INNOWAX ( $60 \mathrm{~m} \times 0.25 \mathrm{mmI} . \mathrm{Dx} 0.25 \mu \mathrm{m}$, film thickness) } \\
\hline Carrier Gas flow & \multicolumn{5}{|c|}{ He at $1 \mathrm{~mL} / \mathrm{min}$. } \\
\hline Injection mode & \multicolumn{5}{|c|}{ Pulsed Splitless } \\
\hline Injection port temp. & \multicolumn{5}{|c|}{$210^{\circ} \mathrm{C}$} \\
\hline Transferline temp. & \multicolumn{5}{|c|}{$210^{\circ} \mathrm{C}$} \\
\hline \multirow[t]{3}{*}{ Oven temp. program } & initial & initial & rate & final & final \\
\hline & temp. $\left({ }^{\circ} \mathrm{C}\right)$ & time(min) & $\left({ }^{\circ} \mathrm{C} / \mathrm{min}.\right)$ & temp. $\left({ }^{\circ} \mathrm{C}\right)$ & time(min.) \\
\hline & 40 & 3 & 8 & 220 & 3 \\
\hline Post run & \multicolumn{5}{|c|}{$220^{\circ} \mathrm{C}, 5 \mathrm{~min}$} \\
\hline
\end{tabular}




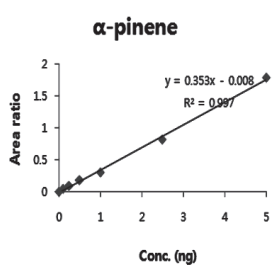

8-3-Carene

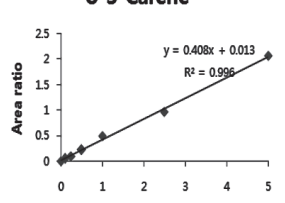

Conc. (ng)

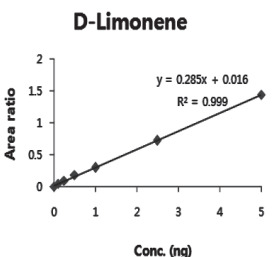

Terpinolene

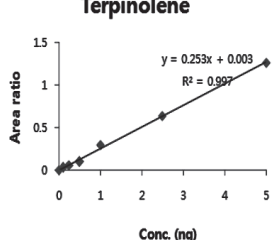

trans-caryophyllene

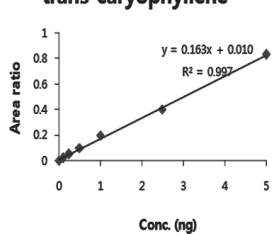

Conc. (ng)

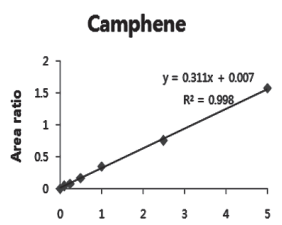

Conc. (ng)

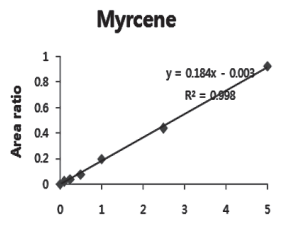

Conc. (ng)
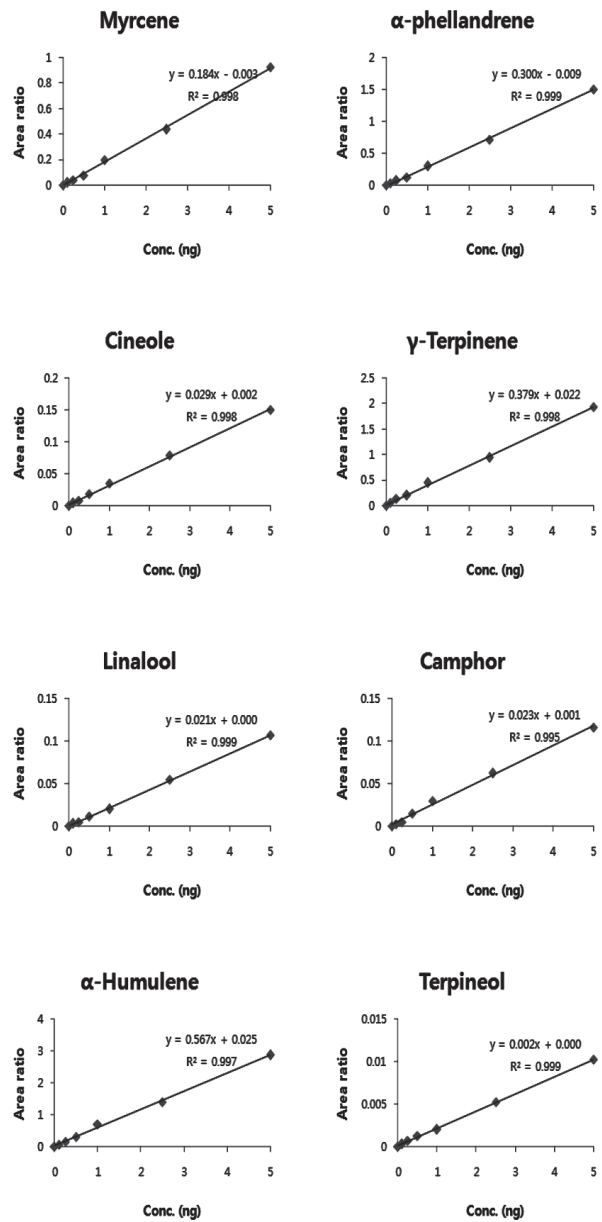

Fig. 1. Calibration curve of measurement materials.

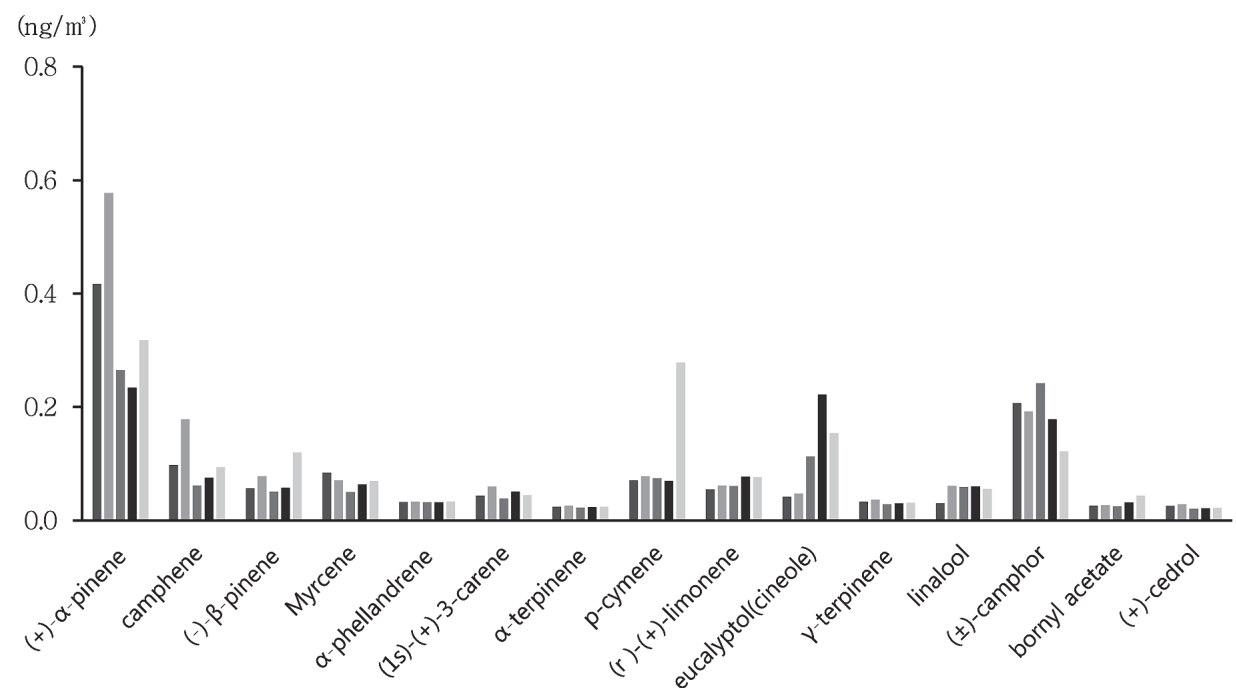

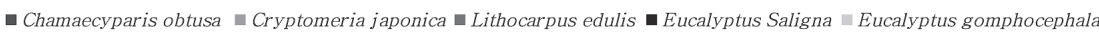

Fig. 2. Variation of NVOCs in the study site.
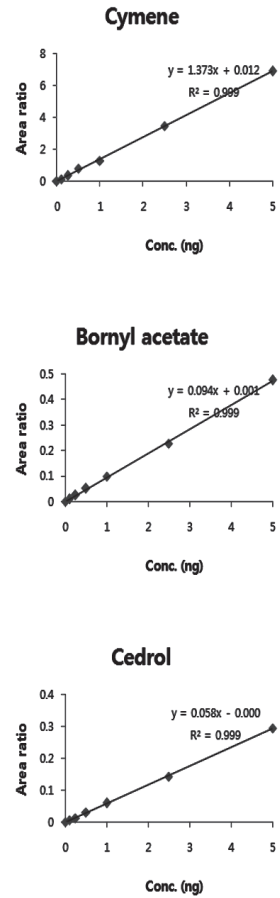

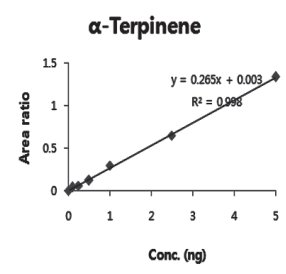


ture of the site were $17.8^{\circ} \mathrm{C}, 97.2 \%, 0.2 \mathrm{~m} / \mathrm{s}$, and $18.1^{\circ} \mathrm{C}$, respectively, and the PMV and PPD were -0.9 and $24.8 \%$, respectively.

\section{L. edulis community}

The L. edulis community had a DBH of $\geq 15 \mathrm{~cm}$ and a gentle slope of $2^{\circ}$ (Fig. 6). The tree layer had an average tree height of $2 \mathrm{~m}$. The average temperature, humid-

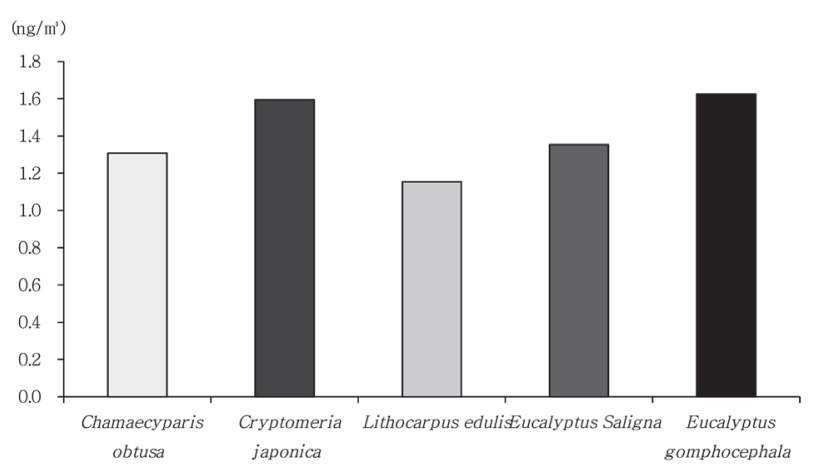

Fig. 3. Variation of TNVOCs in the study site.

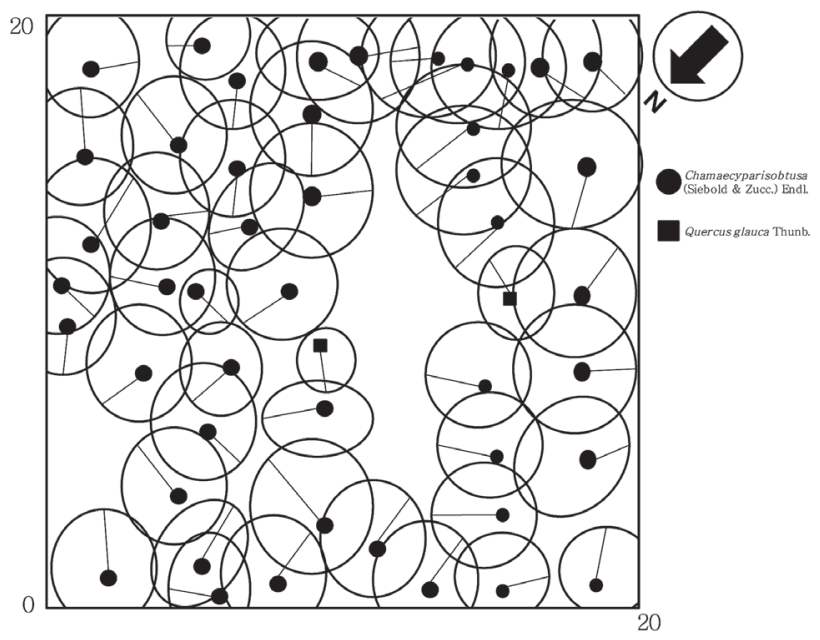

Fig. 4. Crown projection in Chamaecyparis obtusa community.

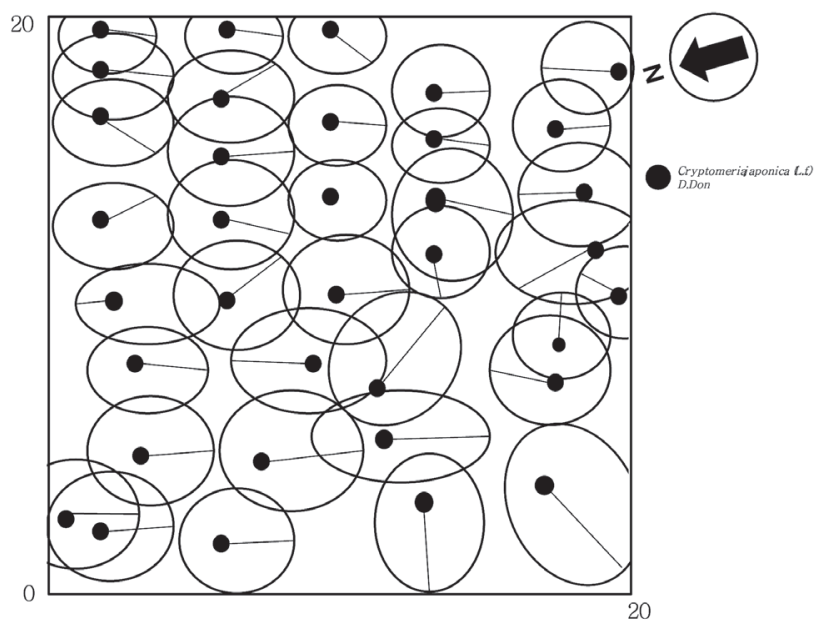

Fig. 5. Crown projection in Cryptomeria japonica community. ity, wind velocity, and black globe temperature of the site were $20.0^{\circ} \mathrm{C}, 83.7 \%, 1.0 \mathrm{~m} / \mathrm{s}$, and $21.9^{\circ} \mathrm{C}$, respectively, and the PMV and PPD were -0.3 and $9.1 \%$, respectively.

\section{E. saligna community}

The $E$. saligna community had a $\mathrm{DBH}$ of $\geq 50 \mathrm{~cm}$ and a gentle slope below $2^{\circ}$ (Fig. 7). The tree layer had an average tree height of $19 \mathrm{~m}$. The average temperature, humidity, wind velocity, and black globe temperature of the site were $20.1^{\circ} \mathrm{C}, 79.8 \%, 0.7 \mathrm{~m} / \mathrm{s}$, and $23.6^{\circ} \mathrm{C}$, respectively, and the PMV and PPD were -0.1 and $6.9 \%$, respectively.

\section{E. gomphocephala community}

The E. gomphocephala community had a DBH of $\geq$ $50 \mathrm{~cm}$ and a relatively gentle slope below $2^{\circ}$ (Fig. 8). The tree layer had an average tree height of $18 \mathrm{~m}$. The average temperature, humidity, wind velocity, and black globe temperature of the site were $22.5^{\circ} \mathrm{C}, 74.4 \%, 0.4 \mathrm{~m} / \mathrm{s}$, and $26.2^{\circ} \mathrm{C}$, respectively, and the PMV and PPD were 0.7 and $17.2 \%$, respectively (Figs. 9 and 10 ).

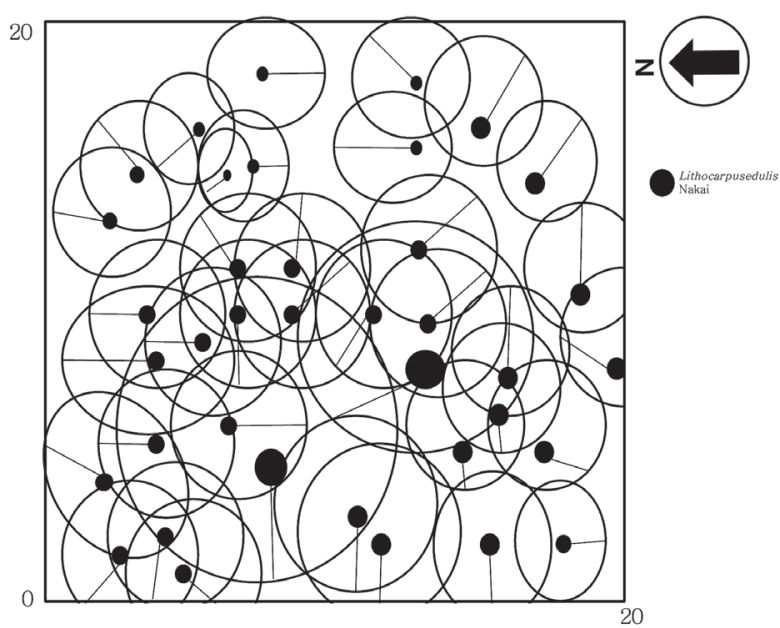

Fig. 6. Crown projection in Lithocarpus edulis community.

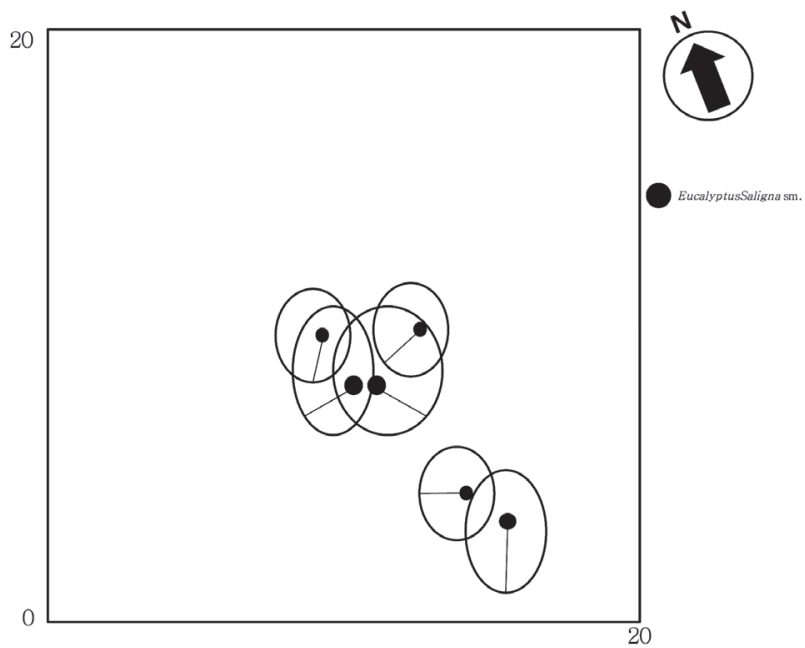

Fig. 7. Crown projection in Eucalyptus saligna community. 


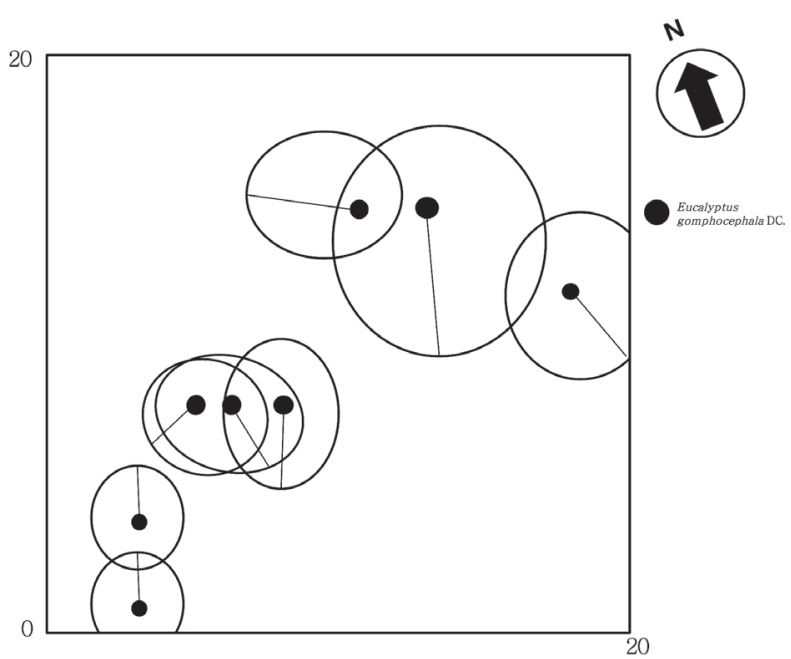

Fig. 8. Crown projection in Eucalyptus gomphocephala community.

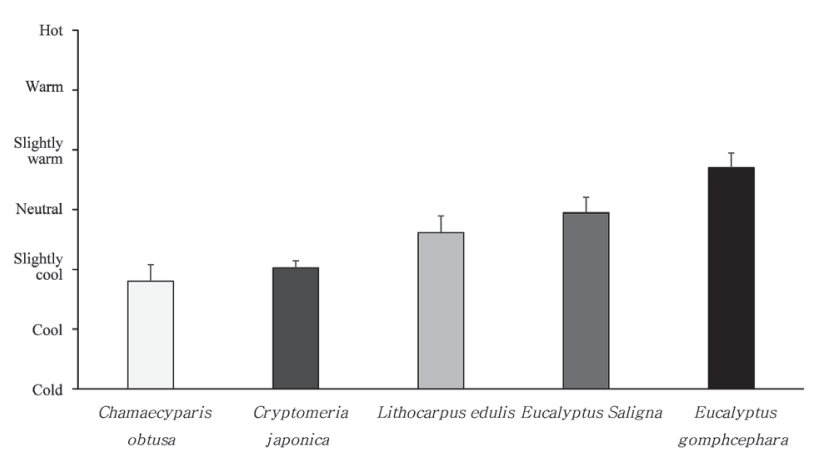

Fig. 9. PMV results in the study site.

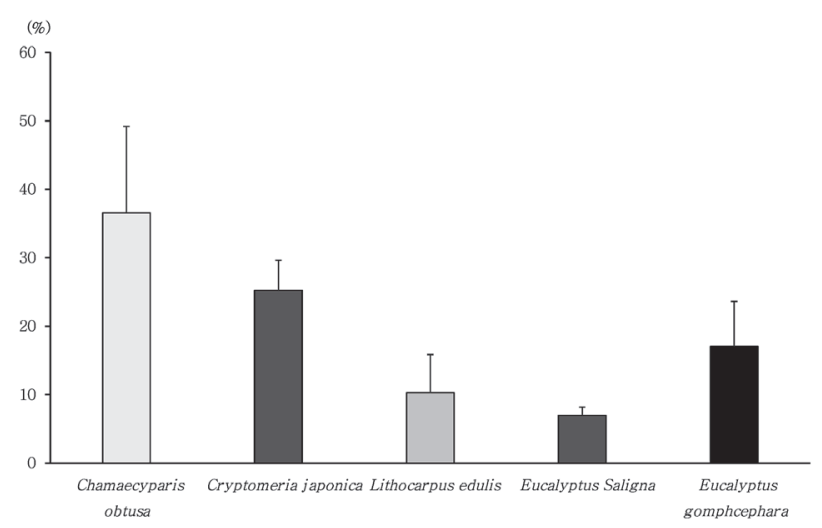

Fig. 10. PPD results in the study site.

\section{DISCUSSION}

This study was performed to present forest healing factors scientifically. An analysis of major forest tree species in the Kasuya Research Forest of Kyushu University was performed to measure the NVOCs concentrations and thermal comfort indexes of PMV and PPD, which are widely known to the general public among the healing factors. A total of 17 substances, including $\alpha$-pinene, were detected as NVOCs emitted from 20 tree species in the study site. They were high in concentration in the order of $\alpha$-pinene $>$ camphor $>$ camphene. According to previous studies, the season-specific emission of NVOCs is related to environmental action, growth amount, and age and oil components of leaves (Janson, 1993; Yatagai et al., 1995; Bertin et al., 1997; He et al., 2000). The monoterpene group of NVOCs is known to have great seasonal differences in composition rates (Staudt et al., 1997; Tani et al., 2002). The present study showed that most NVOCs are similar in composition rate, which is believed to be influenced by temperature, considering that the trees of the site are a thrifty forest low in growth amount. Of the components, $\alpha$-pinene with a high concentration is known to be effective for stress, insect control, depression, oxidation, and sleeplessness (Mckay et al., 2003; Kawakami et al., 2004; Mishra et al., 2012). Analysis of differences in the concentration of the emitted materials among the tree species in the study site showed that a specific tree species shows higher concentration of an emitted material (C. japonica: $\alpha$-pinene $0.578 \mathrm{ng} / \mathrm{m}^{3}$, camphene $0.179 \mathrm{ng} / \mathrm{m}^{3} ; E$. saligna: cineole $0.222 \mathrm{ng} / \mathrm{m}^{3}$; E. gomphocephala: $\beta$-pinene $0.120 \mathrm{ng} / \mathrm{m}^{3}$, cymene $0.279 \mathrm{ng} / \mathrm{m}^{3}$ ). These results are consistent with earlier studies, which reported that the concentration varied according to the oil contained in leaf components. Eucalyptus species produced cineole (eucalyptol) at higher concentration than other species. A previous study (Park et al., 2009) showed that Eucalyptus oil has a psychologically stabilizing effect. Among the tree species, E. gomphocephala emitted the highest concentration of NVOCs $\left(3.13 \mathrm{ng} / \mathrm{m}^{3}\right)$. However, as no significant difference was observed in the concentrations among the tree species, it is necessary to conduct a study that takes the same region and time into consideration to make a clear comparison. In addition, it is important to conduct psychological and physiological studies of the programs and activities in the forest using the NVOCs of high concentration and the materials from specific species. According to the analysis of PMV and PPD, human activities were most comfortable in E. saligna and E. gomphocephala communities. This result is considered to be derived from forest tree density and physico-environmental factors, and activities in Eucalyptus species are expected to be beneficial for human beings both psychologically and physiologically. Hence, citizens are expected to benefit from the programs coupled with exercise therapies and the spatial designs, including recreational space. However, it is deemed necessary to increase the number of tests and elaborate on the differences by topography and tree species. A clearer conclusion can be obtained when a comparative study is conducted in more detail. The data from the present study will be used as beneficial information for citizens and will help understand forests in a novel viewpoint in terms of healing.

\section{ACKNOWLEDGMENTS}

This study was conducted in collaboration with Kyushu University Forests in Japan. The authors thank Professor Kyoichi Otsuki, Kyushu University Forests for valuable discussion and a lot of great help for field researches. This study was performed with the support 
of Forest Science \& Technology Projects (Project No. S211214L010110) provided by the Korea Forest Service.

\section{REFERENCES}

Akutsu, T., S. Tanaka, Y. Murakami, K. Nakajima, Y. Nagashima, Y. Yada, T. Suzuki and K. Sasaki 2006 Effect of the natural fragrance "cedrol" on dopamine metabolism in the lateral hypothalamic area of restrained rats: A microdialysis study. International Congress Series, 1287: 195-200

Bertin, N., M. Staudt, U. Hansen, G. Seufert, P. Ciccioli, P. Foster, J. L. Fugit and L. Torres 1997 Diurnal and seasonal course of monoterpene emissions from Quercus ilex (L.) under natural conditions application of light and temperature algorithms. Trans L. Atmos. Environ., 31: 135-144

Bräred-Christensson, J. B., K. E. Andersen, M. Bruze, J. D. Johansen, B. G. Bravo, A. G. Arnau, C. L. Goh, R. Nixon and I. R. White 2012 Air-oxidized linalool: A frequent cause of fragrance contact allergy. Contact. Dermatitis., 67: 247-259

Dayawansa, S., K. Umeno, H. Takakura, E. Hori, E. Tabuchia, Y. Nagashimac, H. Oosuc, Y. Yadac, T. Suzukic, Y. Onoa and H. Nishijo 2003 Autonomic responses during inhalation of natural fragrance of "Cedrol" in humans. Auton. Neurosci., 108: 79-86

He, C., F. Murray and T. Lyons 2000 Seasonal variations in monoterpene emissions from Eucalyptus species. Chemosphere, 2: 65-76

Honjo T. 2009 Thermal comfort in outdoor environment. Globa.l Environmetal. Res., 13: 43-47

ISO 2005 Ergonomic of the thermal environment -Analytical determination and interpretation of thermal comfort using calculation of the PMV and PPD indices and local thermal comfort criteria. International Standard ISO7730 (Switzerland), pp. $4-12$

Janson R. W. 1993 Monoterpene emissions from Scots pine and Norwegian spruce. J. Geophy. Res., 98: 2839-2850

Kawakami, K., M. Kawamoto, M. Nomura, H. Otani, T. Nabiki and T. Gonda 2004 Effects of phytoncides on blood pressure under restraints stress in SHRSP. Clin. Exp. Pharmacol. Physiol., 31: S27-S28

Kesselmeier J. and M. Staudt 1999 Biogenic Volatile Organic Compounds (VOC): An overview on emission, physiology and ecology. J. Atmos. Chem., 33: 23-88

Kim, S. B., K. H. Kwak and W. H. Jeoung 2003 Mountainous rural economy and University Forest of CNU. J. KFES., 11: 60-66

Kim, Y. S., S. J. Park, E. J. Lee, S. M. Lee, C. H. Ryu, G. S. Kim, J. O. Kim and Y. L. Ha 2008 Antibacterial compounds from Rose Bengal-sensitized photooxidation of $\beta$-Caryophyllene. $J$ Food. Sci., 73: C541-C545

Kordali, S., A. Cakir, H. Ozer, R. Cakmakci, M. Kesdek and E. Mete 2008 Antifungal, phytotoxic and insecticidal properties of essential oil isolated from Turkish Origanum acutidens and its three components, carvacrol, thymol and $p$-cymene. Bioresour. Technol., 99: 8788-8795

Li, Q., A. Nakadai, H. Matsushima, Y. Miyazaki, A. M. Krensky, T. Kawada and K. Morimoto 2006 Phytoncides (wood essential oils) induce human natural killer cell activity. Immunopharm. Immunot., 28: 319-333

Mckay, S. A. B., L. H. William, K. A. Godard, S. X. Wang, D. M. Martin, J. Bohlmann and L. P. Aine 2003 Insect attack and wounding induce traumatic resin duct development and gene expression of $(\alpha)$-pinene synthase in Sitka spruce. Plant. Physiology., 133: 368-378

Mishra, A. K., A. Mishra, A. Verma and P. Chattopadhyay 2012 Effects of Calendula essential oil-based cream on biochemical parameters of skin of albino rats against ultraviolet B radiation. Sci. Pharm., 80: 669-683

Ohira T. and N. Matsui 2012 Forest medicine. Nova Science Publishers (USA), pp. 25-34

Osman, C., O. Ilknur, T. Sadettin, S. Yildiz and H. Oguzturk 2011 Antioxidative effects of curcumin, b-myrcene and 1,8-cineole against 2,3,7,8-tetrachlorodibenzo-p-dioxin induced oxidative stress in rats liver. Toxicol. Ind. Health., 27(5): 447-453

Park, B. J., Y. Tsunetsugu, T. Kasetani, T. Kagawa and Y. Miyazaki 2010 The physiological effects of Shinrin-yoku (taking in the forest atmosphere or forest bathing): Evidence from field experiments in 24 forests across Japan. Environ. Health. Prev. Med., 15(1): 18-26

Park, B. J., T. Morikawa, T. Ogata, K. Washida, M. Iwamoto, H. Nakamura and Y. Miyazaki 2009 Physiological effects of ingesting Eucalyptus essential oil with milk Casein Peptide. Silva Fenica, 43: 173-179

Staudt M., N. Bertin, U. Hansen, G. Seufert, P. Ciccioli, P. Foster, B. Frenzel and J. L. Fugit 1997 Seasonal and diurnal patterns of monoterpene emissions from Pinus pinea (L.) under field conditions. Trans L. Atmos. Environ., 31: 145-156

Takayama, N., T. Kagawa, T. Kasetani, B. J. Park, Y. Tsunetsugu, Y Oishi, H. Hirano and Y. Miyazaki 2005 The comfortableness of the light/thermal environment for bathing in the forest atmosphere. Journal of The Japanese Institute of Landscape Architecture, 68(5): 819-824

Tani, A., S. Nozoe, M. Aoki and C. N. Hewitt 2002 Monoterpene fluxes measured above a Japanese red pine forest at Oshiba plateau, Japan. Atmos. Environ., 36: 3391-3402

Wang, W., N. Li, M. Luo, Y. Zu and Thomas E. 2012 Antibacterial activity and anticancer activity of Rosmarinus officinalis L essential oil compared to that of its main components. Molecules, 17: 2704-2713

Yatagai, M., M. Ohira, T. Ohira and S. Nagai 1995 Seasonal variations of terpene emission from trees and influence of temperature, light and contact stimulation on terpene emission. Chemosphere, 30: 1137-1149 